TITLE:

\title{
Investigation of Nuclear Reactions Induced by High Energy Bremsstrahlung(Abstract_要旨 )
}

AUTHOR(S):

Masaike, Akira

CITATION:

Masaike, Akira. Investigation of Nuclear Reactions Induced by High Energy Bremsstrahlung. 京都大学, 1964, 理学博士

\section{ISSUE DATE:}

1964-06-23

URL:

http://hdl.handle.net/2433/211312

RIGHT: 


\section{[ 16 】}

氏 名

学位の種 類 学位記番号 学位授与の日付 学位授与の要件 研究科. 尃攻 学位論文題目
政池

理学
明

あきら

理 博 第 80 号

昭 和 39 年 6 月 23 日

学位規則第 5 条第 1 項該当

理学研究科物理学專攻

Investigation of Nuclear Reactions Induced by High

Energy Bremsstrahlung

（高エネルギー制動輻射による核反応の研究）

論文調查委員教 主授查) 見真次郎 教 授小林 稔 教 授 四手井綱彦

\section{論 文内容 の 要旨}

主論文において著者は原子核研究所 $750 \mathrm{MeV}$ 電子シンクロトロンの $\gamma$ 線ビームを用いて $150 \mathrm{MeV} \sim$ $720 \mathrm{MeV}$ のエネルギー範囲において反応で生成される放射能を測る方法すなおち Activation 法によっ てアルミニウム，炭素及び銅についての種々の光反応断面積を測定している。一般に中間子閾值以上のエ ネルギーに抢ける原子核光反応断面積の測定は，核内核子からの中間子光発生，発生した中間子の核内で の散乱および吸収，核内核子の運動量分布および核子間の相関等の諸点から甚だ興味深い。

現在までになされた実験的研究においては主として限られたエネルギー範囲の放出粒子を特定の二，三 の角度で測定しており，反応の全断面積を求める上には不便なととが多い。さらに中間子一核子系のいわ ゆる $(3 / 2,3 / 2)$ 共鳴が原子核の光反応に拈いてどのように現われるかという問題についてはきわめて測定 值に乏しくほとんぞ知られていない。

上記の問題を Activation 法で測定することは次の点ですぐれている。すなわちこの方法によると特定 の反応の全断面積が測りうる。したがって $r$ 線に対する原子核の昅収全断面積を算定するのに非常に有用 なデータとなる。さらに放出粒子测定に比し $r$ 線エネルギーを变えてその反応の励起曲線をとるととが比 較的容易である。

Activation 法による高エネルギー光核反応の研究は現在まで数種の反応に刘して約 $300 \mathrm{MeV}$ までの

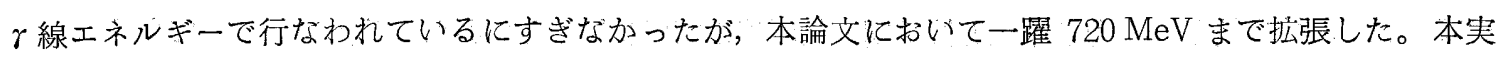
験においては反応生成の割合の測定には $4 \pi-\beta$ 計数管による $\beta$ 線の絶対測定法と NaI (T1) シンチレー ション計数管による $\gamma$ 計数法とを用い，反応の型の決定には減衰曲線から求めた半減期と $\gamma$ 線スペクト ロスコピーとを併用した。両者の間の一致は非常に良い。入射 $\gamma$ 線の強度の測定は，著者を含む数人の研 究者が原子核研究所で製作したウイルソン型Quantameterを用いてなされた。この種の実験において特 に慎重を要する中性子バックグランドについては著者は注意深い一連の補助測定を行なっており：この影 響が各々の場合に抬いて $1 \sim 3 \%$ 以下であるてとを確かめている。 $4 \pi-\beta$ 計数管による $\beta$ 線の絶対测定法 
とは，種々の厚さの同一資料についての規格化された測定值を厚さ０に外插する方法であるが，乙れは絶 対測定法としては最も信頼に足るものであって，乙れについては参考論文その3にくわしく述べられてい る。

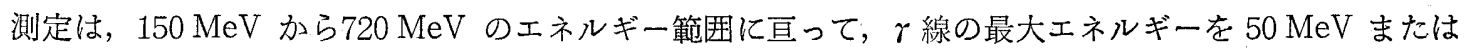
$100 \mathrm{MeV}$ ずつ変えて行なわれた。 $\mathrm{C}^{12} \rightarrow \mathrm{C}^{11}$ および $\mathrm{Cu}^{\prime} \rightarrow \mathrm{Cu}^{62}$ 反応においては，中間子閾值以下であ反 応がかなり起こっているが，とれは主としていわゆる巨大共鳴によるものである。銅の場合は炭素の時よ り巨大共鳴の寄与がずっと大きいのでその Activation Curve はほとんどェネルギー軸に平行である。 この二つの反応の場合を除けば， $\pi$ 中間子の質量に相当する $\gamma$ 線エネルギーを起点として， Activation Curve は急激に上昇し，400 MeV 付近でゆるやかになっている。かくして著者は $\mathrm{Al}^{27}\left(\gamma, \pi^{*}\right) \mathrm{Mg}^{27}$, $\mathrm{Al}^{27} \rightarrow \mathrm{Na}^{24}, \mathrm{Al}^{27} \rightarrow \mathrm{F}^{18} ， \mathrm{C}^{12} \rightarrow \mathrm{C}^{11}$ 反応について $200 \mathrm{MeV}$ 加ら $400 \mathrm{MeV}$ のエネルギー範囲におりる 積分断面積の値として，夫々， $2.2 \times 10^{-26} \mathrm{~cm}^{2} . \mathrm{MeV}, 6.2 \times 10^{-26} \mathrm{~cm}^{2} . \mathrm{MeV}, 2.4 \times 10^{-26} \mathrm{~cm}^{2} . \mathrm{MeV}$, 及

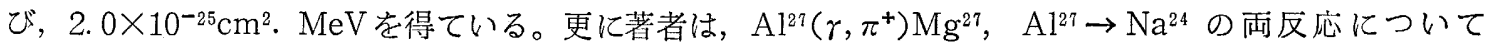
は，いわゆる Photon difference 法によって反応の励起曲線を求めている。両者の場合について，いず れ6約 $300 \mathrm{MeV}$ 付近に極大のある共鳴型の曲線が得られた。著者はこれを中間子一核子系のいわゆる $(3 / 2,3 / 2)$ 共鳴の形と比較し， $\mathrm{A} 1^{27} \rightarrow \mathrm{Na}^{24}$ の場合はピークの位置はほとんど変わらないが，幅が広くな っていることを指摘し,てれは多分，核内核子の運動量分布のためと推論している。また $\mathrm{Al}^{27}\left(\gamma, \pi^{+}\right) \mathrm{Mg}^{27}$ の場合については，核子の場合に比してピークの位置はやや高エネルギー側にずれており，且つ，その幅 は広くなり，更に $500 \mathrm{MeV}$ 以上の高エネルギ一側で核子の場合には曲線は上昇するに比し逆に下降して いることを認めた。この下降の原因は，r線のエネルギーが高くなるにつれて，核内において中間子の発 生する際反跳された核子のエネルギーも大きくなり，核外に飛び出す確率が増えるため $\left(\gamma, \pi^{+}\right)$反応は少 なくなると推論している。

参考論文その $1 ， 2 ， 4 ， 5 ， 6$ 及び 7 はいわゆる低エネルギー核反応に関するあのであって，(p， $\alpha)$ 及 び（d， $\alpha$ ) 反応で放出される粒子の角分布の測定から反応機構や核の構造を解明せんとするすのである。 参考論文その 3 は低エネルギー光核反応断面積の絶対值に関するあのであり，その８は主論文の研究の予 備的段階における速報である。

\section{論 文賽 查の結 果の 要 旨}

高エネルギー領域における原子核光反応の研究は，核内核子からの中間子光発生，発生した中間子の核 内での吸収，核内核子の運動量分布と核子間の相関等の問題に関連して甚だ興味深いテーマである。

主論文はこの問題を，約 2 年前完成した原子核研究所 $750 \mathrm{MeV}$ 電子シンクロトロンの い, Activation 法で断面積の絶対值を湘定したものである。その際 $\boldsymbol{\gamma}$ 線の最大エネルギーを $50 \mathrm{MeV}$ ま たは $100 \mathrm{MeV}$ ずつ変化して $150 \mathrm{MeV}$ より $720 \mathrm{MeV}$ のエネルギー範囲に亘っていわゆる Activation Curve を求め, 中間子一核子系のいわゆる $(3 / 2,3 / 2)$ 共鳴のピークのエネルギー約 $300 \mathrm{MeV}$ を心と する $200 \mathrm{MeV}$ から $400 \mathrm{MeV}$ までの積分断面積の絶対值を数種の反応に対して決定した。さらにアルミ ニウム原子核について $\pi^{+}$中間子のみが放出される反応および最終的に $\mathrm{Na}^{24}$ が生成される反応に対して, 
Photon difference の方法を啇用して反応の励起曲線を求めている。てれによってあし反応における放出 粒子の分岐比がこのエネルギー範囲において変化しないと仮定すれば，中間子一核子系の $(3 / 2,3 / 2)$ 共鳴 の効果が原子核光反応においても明瞭に現われているととおよびその共鳴幅はおそらく核内核子の運動量 分布を反映して広くなっているてとを見出している。

これは上述の問題点之密接に関連して甚だ重要な実験結果であり，原子核光反応において $(3 / 2,3 / 2)$ 共 鳴の影響を最初に実験的に見出した点は特に高く評価される。さらに著者は得られた積分断面積の絶対値 と核子からの中間子の光発生断面積の実験值とを比較検討して種々興味ある議論を展開しているが， こ れらは高エネルギー光核反応の今後の研究に対して基礎的な足脚りを提供しているすのといえる。特に $\mathrm{Al}^{27}\left(\gamma, \pi^{+}\right) \mathrm{Mg}^{27}$ 反応のように $\pi^{+}$中間子のみが放出される反応は高エネルギー光核反応機構の解明に有 用な知識を与えるあのと考えられる。

以上のように主論文は高エネルギー光核反応の分野に扔いて新しい知見を加えたものであって貢献する ところが大である。参考論文その $1 ， 2 ， 4 ， 5 ， 6$ 抢び 7 はいわゆる低エネルギー核反応に関するもので あって，(p， $\alpha)$ および（ $\mathrm{d} ， \alpha)$ 反応で放出される粒子の角分布の測定汃ら反応機構や核の構造を究明し ようとするすのであり，参考論文その 3 は低エネルギー光核反応断面積の絶対值に関するすのであってい ずれも価值ある結果を得ており，著者が原子核物理学の広い分野にわたって豊富な知識とすぐれた研究能 力をもっているととを示している。

以上の点にかんがみ本論文は理学博士の学位論文として価值があるものと認める。 